\title{
HAEMATOLOGICAL INDICES AND BLOOD LIPID PROFILE OF RATS ADMINISTERED TRONA; A NATURAL FOOD ADDITIVE.
}

\author{
${ }^{1}$ Imafidon Kate Evbu* ${ }^{1}$ Omoregie Ivie Precious and ${ }^{1}$ Egberanmwen \\ Doris Iriagbonse
}

${ }^{1}$ DEPARTMENT OF BIOCHEMISTRY, FACULTY OF LIFE SCIENCES, UNIVERSITY OF BENIN.

\section{Received 29/11/2015- Accepted 1/1/2016}

\begin{abstract}
Trona, a geological mineral is often used as a natural food additive in many parts of Africa. This work was done to evaluate trona for elemental content and ascertain its effect on body weight changes; lipid profile and haematological indices as part of safety assessment. Consequently twenty-four rats were divided into four groups of six rats each. The first group served as the control while the other groups were administered 10, 100, and $1000 \mathrm{mg}$ trona per $\mathrm{kg}$ body weight for a period of 28 days. Elemental analysis revealed the presence of high concentrations of sodium and iron. Results revealed dose dependent increase in triacylglycerol levels; however cholesterol, HDL cholesterol, LDL cholesterol, and haematological indices were not significantly affected.
\end{abstract}

Key words: Trona; additive; sodium; triacylglycerol; haematological

\section{INTRODUCTION}

Trona is used in many African countries e.g Mali, Burkina Faso, Niger, Chad, Nigeria and Ghana. It is an important ingredient in a variety of cereal based foods e.g "massa" (Nkanma and malteshi, 1998). It is erroneously called potash although it contains low amount of potassium compared to sodium. It is the second most commonly used salt in Nigeria.

Trona is a sesquicarbonate containing $\mathrm{Na}_{2} \mathrm{CO}_{3}$ and $\mathrm{NaHCO}_{3}$ in equimolar proportion, a dry lake salt (Oyeleke and Morten, 1981). Its

* Correspondence Author (e mail: (katev6u@gmail.com) 
main uses are in cooking tough food materials such as skins, bones, beans, maize, soups and sauces. Its chemistry is misunderstood by those describing it as potash. The effect of trona on cooking time was reported by Edijela (1980). It was observed that trona reduced the cooking time of legumes. Studies have indicated that high levels of trona in cooked foods and drinking water may be detrimental to health (Oyeleke, 1988) and hemolytic to humans (Sodipo et al, 1993)

Lipid profiles are risk indicators of coronary heart disease (Edem, 2002). Strong correlations have been shown between increased plasma total cholesterol, low density lipoprotein cholesterol and increased incidence of coronary heart disease (Edionwe and Kies, 2001). Haematology refers to the study of the numbers and morphology of the cellular elements of the blood, these are the red cells (erythrocytes), white cells (leucocytes) and the platelets (thrombocytes) and the use of these results in diagnosis and monitoring of disease.

Changes in haematological parameters are often used to determine various status of the body and to determine stresses due to environmental, nutritional and/or pathological factors. To the best of our knowledge, no work has been done on the effect of trona on lipid profile and haematological indices. This work was done to bridge this gap in knowledge.

\section{MATERIALS AND METHODS}

Source of materials: Trona was purchased from Uselu market, Edo state, Nigeria, and identified by Dr O.I Imasuen, Department of Geology, University of Benin, Edo state, Nigeria.

Metal content analyses

Exactly $1 \mathrm{~g}$ of powdered trona was ashed at $500^{\circ}$ for three hours. The ash was dissolved in $10 \mathrm{ml} 20 \% \mathrm{HNO}_{3}$, filtered into a $100 \mathrm{ml}$ volumetric flask and used for elemental analysis. Zinc, Iron, Cadmium, manganese, lead, sodium, potassium and copper were determined using an acetylene air flame (Atomic Absorption Spectrophotometer, 969 Uracan Series model) (Skoog et al., 2007).

Animals

Male Albino rats (wistar strain) were obtained from the animal House of the Department of Anatomy, University of Benin, Edo state, Nigeria. They were fed commercially formulated rat feed and water 
ad libitum. The animals (24) were divided into 4 groups of 6 rats each. The first group serve as the control, groups II, III, and IV were administered $10,100,1000 \mathrm{mg} / \mathrm{kg}$ intraperitonealy for a period of 28 days. The principles of laboratory animal care (NIH Publication, 1985) were followed.

\section{Chemicals}

All chemicals used were of the analytical grade. Assay kits (Crumlin Co Anthrim, Spain) were used to estimate triacyglycerol, cholesterol, LDL and HDL cholesterol levels.

Blood sample collection

At the end of the treatment blood samples were collected by direct cardiac puncture into sterile containers with anticoagulant.

Biochemical analysis

Plasma triacylglycerol, cholesterol, HDL and LDL cholesterol were determined by using standard ready-to-use kits and methods of Randox Laboratories (Randox Laboratories, Crumlin,Co. Anthrim, UK) The manufacturer's instructions for each biochemical parameter were strictly followed in the course of the investigations. Cholesterol and triacylglycerol concentrations were determined after enzymatic hydrolysis. High density lipoprotein (HDL) was obtained by precipitation of very low density lipoprotein (VLDL), low density lipoprotein (LDL) and used to chylomicron fractions. The equation of Friedewald et al., (1972) was estimate LDL cholesterol concentration. Haematological indices were estimated using the ERMA PCE - 210 automated haematological analyser. The machine is an automatic multi parameter blood cell counter for in - vitro diagnostic use in clinical Laboratories. It performs eighteen haematological parameters analyses on whole blood collected with an anti - coagulant or freshly collected and manually diluted.

Statistical analysis

All data were expressed as mean \pm SEM $(n=6)$. One way analysis of variance was used to test for difference among all the groups. Dunnett's multiple range tests was used to test for significant differences among the means. A $\mathrm{p}$ value of $<0.05$ was considered statistically significant. 


\section{RESULTS}

Results on the elemental analysis of trona (table 1) revealed a high concentration of sodium and iron, followed by zinc and copper. Heavy metals such as cadmium and lead were also present. Increases in weights were observed in all the experimental rats (table 2). There were no significant differences in weight gain of test rats when compared with control. Results on the effect of trona on blood lipid profile are presented on table 3.

There were dose dependent increases in triacylglycerol levels compared with control. Cholesterol, HDL and LDL cholesterol levels were not significantly affected. Red blood cell indices of rats administered 10, 100 and $1000 \mathrm{mg} / \mathrm{kg}$ of trona were not significantly affected compared with control (table 4). The results on the effects of trona on white blood cell indices are presented on table 5. There were no significant differences in white blood cells and lymphocytes between the test rats compared with the control. A non-dose dependent effect was observed on monocyte and granulocyte. Platelets and its differentials were not significantly altered in rats administered the graded doses of trona compared with control (table 6).

Table 1 : Elemental analysis of trona

\begin{tabular}{|lc|}
\hline Element & Concentration (\%) \\
\hline Potassium & $0.22 \pm 0.01$ \\
Magnesium & $0.02 \pm 0.00$ \\
Calcium & $0.05 \pm 0.00$ \\
Sodium & $23.47 \pm 3.07$ \\
Zinc $\left(\mathbf{x 1 0}^{-3}\right)$ & $0.05 \pm 0.06$ \\
Iron $\left(\mathbf{x 1 0}^{-3}\right)$ & $1.29 \pm 0.27$ \\
Cadmium $\left(\mathbf{x 1 0}^{-3}\right)$ & $0.10 \pm 0.01$ \\
Manganese $\left(\mathbf{x 1 0}^{-3}\right)$ & $0.30 \pm 0.00$ \\
Lead $\left(\mathbf{x 1 0}^{-3}\right)$ & $0.10 \pm 0.00$ \\
Copper $\left(\mathbf{x 1 0}^{-3}\right)$ & $0.57 \pm 0.01$ \\
\hline
\end{tabular}

Results are expressed as mean \pm sem $(n=4)$. 
Table 2 : Effect of trona on body weight changes

\begin{tabular}{|lc|}
\hline Treatment & Weight changes $(\mathbf{g})$ \\
\hline Control & $30.20 \pm 4.78^{\mathrm{a}}$ \\
$\mathbf{1 0} \mathbf{~} \mathbf{~} / \mathbf{k g}$ & $27.34 \pm 1.52^{\mathrm{a}}$ \\
$\mathbf{1 0 0} \mathbf{~} \mathbf{m g} / \mathbf{k g}$ & $31.90 \pm 3.37^{\mathrm{a}}$ \\
$\mathbf{1 0 0 0} \mathbf{~ m g} / \mathbf{g}$ & $28.33 \pm 5.94^{\mathrm{a}}$ \\
\hline
\end{tabular}

Results are expressed in mean \pm sem $(n=6)$. Similar superscript (a) denotes insignificance at $\mathrm{p}<0.05$.

Table 3 : Effect of trona on plasma lipid profile (mg/dl)

\begin{tabular}{|c|c|c|c|c|}
\hline Treatment & $T A G$ & Cholesterol & $H D$ & $L D L$ \\
\hline Control & $13.21 \pm 1.76^{\mathrm{a}}$ & $89.37 \pm 3.61^{\mathrm{a}}$ & $75.42 \pm 3.91^{\mathrm{a}}$ & $13.95 \pm 0.70^{\mathrm{a}}$ \\
\hline $10 \mathrm{mg} / \mathrm{kg}$ & $33.02 \pm 3.79^{b}$ & $91.30 \pm 4.63^{\mathrm{a}}$ & $73.39 \pm 4.87^{\mathrm{a}}$ & $17.91 \pm 3.78^{\mathrm{a}}$ \\
\hline $100 \mathrm{mg} / \mathrm{kg}$ & $42.68 \pm 4.42^{c}$ & $94.16 \pm 1.56^{\mathrm{a}}$ & $76.28 \pm 4.47^{\mathrm{a}}$ & $17.88 \pm 1.51^{\mathrm{a}}$ \\
\hline $1000 \mathrm{mg} / \mathrm{kg}$ & $44.97 \pm 1.26^{\mathrm{c}}$ & $102.14 \pm 2.50^{\mathrm{a}}$ & $87.70 \pm 0.69^{a}$ & $14.44 \pm 1.04^{\mathrm{a}}$ \\
\hline
\end{tabular}

Results are expressed as mean \pm sem $(n=6)$. Different superscripts (a, b and c) denotes significance at $\mathrm{p}<0.05$ compared with control.

Table 4 : Effects of trona on red blood cell indices of rats.

\begin{tabular}{|lcccc|}
\hline & Control & $10 \mathrm{mg} / \mathrm{kg}$ & $100 \mathrm{mg} / \mathrm{kg}$ & $1000 \mathrm{mg} / \mathrm{kg}$ \\
\hline RBC (x10 $/ \mathbf{u l})$ & $8.45 \pm 0.28^{\mathrm{a}}$ & $8.32 \pm 0.55^{\mathrm{a}}$ & $7.77 \pm 0.56^{\mathrm{a}}$ & $8.64 \pm 0.28^{\mathrm{a}}$ \\
Hgb (g/dl) & $15.53 \pm 0.55^{\mathrm{a}}$ & $15.77 \pm 0.95^{\mathrm{a}}$ & $14.67 \pm 0.87^{\mathrm{a}}$ & $15.93 \pm 0.55^{\mathrm{a}}$ \\
HCT (\%) & $43.10 \pm 1.73^{\mathrm{a}}$ & $45.57 \pm 1.55^{\mathrm{a}}$ & $42.73 \pm 1.68^{\mathrm{a}}$ & $47.17 \pm 2.66^{\mathrm{a}}$ \\
MCV (fl) & $50.97 \pm 1.11^{\mathrm{a}}$ & $54.87 \pm 4.19^{\mathrm{a}}$ & $55.03 \pm 1.88^{\mathrm{a}}$ & $54.50 \pm 1.35^{\mathrm{a}}$ \\
MCH (pg) & $18.37 \pm 0.45^{\mathrm{a}}$ & $18.93 \pm 0.49^{\mathrm{a}}$ & $18.47 \pm 0.29^{\mathrm{a}}$ & $18.37 \pm 0.06^{\mathrm{a}}$ \\
MCHC (g/dl) & $36.03 \pm 1.63^{\mathrm{a}}$ & $34.27 \pm 1.54^{\mathrm{a}}$ & $34.27 \pm 0.93^{\mathrm{a}}$ & $33.77 \pm 0.76^{\mathrm{a}}$ \\
RDW (\%) & $17.00 \pm 0.85^{\mathrm{a}}$ & $17.50 \pm 0.81^{\mathrm{a}}$ & $17.47 \pm 0.90^{\mathrm{a}}$ & $18.30 \pm 0.62^{\mathrm{a}}$ \\
\hline
\end{tabular}

Results are presented in mean \pm sem $(n=6)$. Similar superscript (a) denotes insignificance at $\mathrm{p}<0.05$ compared with control. 
Table 5 : Effects of trona on white blood cell indices $\left(x 10^{3} / u l\right)$ of rats.

\begin{tabular}{|c|c|c|c|c|}
\hline & ontrol & $10 \mathrm{mg} / \mathrm{kg}$ & $100 \mathrm{mg} / \mathrm{kg}$ & $1000 \mathrm{mg} / \mathrm{kg}$ \\
\hline WBC & $6.57 \pm 0.46^{\mathrm{a}}$ & $8.33 \pm 0.43^{\mathrm{a}}$ & $8.03 \pm 0.16^{\mathrm{a}}$ & $8.80 \pm 2.15^{\mathrm{a}}$ \\
\hline Lymphocytes & $5.53 \pm 1.31^{\mathrm{a}}$ & $4.57 \pm 1.36^{\mathrm{a}}$ & $7.07 \pm 0.31^{\mathrm{a}}$ & $7.71 \pm 1.02^{\mathrm{a}}$ \\
\hline Monocytes & $0.40 \pm 0.02^{\mathrm{a}}$ & $1.07 \pm 0.10^{\mathrm{b}}$ & $0.40 \pm 0.06^{\mathrm{a}}$ & $0.63 \pm 0.04^{\mathrm{a}}$ \\
\hline Granulocytes & $0.50 \pm 0.01^{\mathrm{a}}$ & $2.77 \pm 0.04^{b}$ & $0.57 \pm 0.05^{\mathrm{a}}$ & $1.00 \pm 0.08^{c}$ \\
\hline
\end{tabular}

Results are expressed as mean \pm sem $(n=6)$. Different superscripts ( $a, b$ and c) denotes significance at $\mathrm{p}<0.05$

Table 6 : Effects of trona on platelet indices

\begin{tabular}{|c|c|c|c|c|}
\hline & Platelet $\left(\times 10^{3}\right)$ & PCT (\%) & MPV (fl) & PDW (\%) \\
\hline Control & $431.00 \pm 51.01^{\mathrm{a}}$ & $0.22 \pm 0.05^{\mathrm{a}}$ & $5.10 \pm 0.30^{\mathrm{a}}$ & $32.00 \pm 3.08^{\mathrm{a}}$ \\
\hline $10 \mathrm{mg} / \mathrm{kg}$ & $361.33 \pm 20.98^{\mathrm{a}}$ & $0.21 \pm 0.02^{\mathrm{a}}$ & $5.67 \pm 0.55^{\mathrm{a}}$ & $40.57 \pm 10.02^{a}$ \\
\hline $100 \mathrm{mg} / \mathrm{kg}$ & $428.67 \pm 94.29^{a}$ & $0.23 \pm 0.06^{\mathrm{a}}$ & $5.37 \pm 0.46^{\mathrm{a}}$ & $43.67 \pm 6.81^{\mathrm{a}}$ \\
\hline $1000 \mathrm{mg} / \mathrm{kg}$ & $503.00 \pm 53.70^{\mathrm{a}}$ & $0.26 \pm 0.06^{\mathbf{b}}$ & $5.20 \pm 0.56^{\mathrm{a}}$ & $32.07 \pm 1.46^{\mathrm{c}}$ \\
\hline
\end{tabular}

Results are presented as mean \pm sem $(n=6)$. Different superscripts $(a, b$ and c) denotes significance at $\mathrm{p}<0.05$.

\section{DISCUSSION}

Work done on the metal content analyses of trona (table 1) revealed high sodium content followed by Iron and very low levels of magnesium, calcium and chromium. Cadmium, zinc and lead were also present. The presence in food and drugs of metals such as cadmium, zinc and lead, which are injurious to health, is regulated by law. These metals are known as heavy metals and are only allowed in trace amounts in foods (Okunrobo et al, 2012). The toxic effects of an additive can be evaluated by monitoring changes in body weight of animals; there were no significant differences in weight gain of test rats compared with control (table 2). Results on lipid profile (table 3) shows significant increases in plasma triacylglycerol, although cholesterol levels were not affected. Increases in plasma 
triacylglycerol levels imply a negative effect on energy metabolism as free fatty acids are not released for uptake by tissues.

Triacylglycerol lipase hydrolyzes triacylglycerol to free fatty acids which are carried by serum albumin to adipose tissues and other tissues. Inhibition of this enzyme may have resulted in the increase in plasma triacylglycerol levels observed. Cholesterol, HDL cholesterol and LDL cholesterol levels were not significantly affected. Some works have been done on the effect of artificial dyes on blood lipid profile; Imafidon and Okunrobo (2011) reported a dose dependent increase in LDL cholesterol and a dose dependent decrease in HDL cholesterol on administration of sudan iv dye to albino rats. AboelZahab et al., (1997) observed significant increases in serum total lipids, cholesterol and triacylglycerol in rats whose diets were supplemented with tartrazine and carmoisine.

Dietary components have been shown to have measurable effects on blood components (Church et al., 1984). Imafidon and Okunrobo,(2011) reported increases in white blood cells and platelets on administration of sub lethal levels of sudan iv dye. However, the results of this study show that this additive has no significant effect on the haematological indices of rats (tables 4, 5 and 6).

CONCLUSION: Trona increased plasma triacylglycerol levels but had no effect on cholesterol, HDL cholesterol and LDL cholesterol. Haematological indices were also not significantly affected by the administration of trona.

\section{REFERENCES}

Aboel-Zahab, H., El-Khyat, Z., Sidhom, G., Awadallah, R., Abdelal, W. and Mahdy, K. (1997). Physiological effects of some food colouring additives on rats. Boll. Chim. Farm. 136 (10):615-627 Church, J.P. Young, J.T., Kebay, C. W. and Kin, W. W. (1984). Relationships among dietary constituents and specific serum clinical components of subjects eating self-selected diet. Am. J. Clin. Nutr. 40:1338-1344.

Edem, D. O. (2002). Palm oil, Biochemical, Physiological aspects, a review. Plant Foods. Hum. Nutr. 57:319-341

Edijala, S.K. (1980). Effects of processing on protein content of cowpea. Food Technol. 15: 445-455

Edionwe, A. O. and Kies, C. (2001). Compression of palm and mixtures of refined palm and soyabeans oils on serum lipids and 
faecal fat and fatty acid excretion of adult humans. Plant Foods. Human Nutr. 56:157-165.

Friedewald, W. T., Levy, R. I. and Fredrickson, D. S. (1972). Estimation of the concentration of low density lipoprotein cholesterol in plasma without the use of the preparative ultracentrifuge. Clin. Chem. 18:499-508.

Imafidon, K.E. and Okunrobo, L.O. (2011). Effects of sudan iv dye on haemato-biochemical indices in rats. Nig. J. Life Sci. 1(1):90-94.

Nkanma L and Maileshi, G. N. (1998). Production and nutritional quality of traditional Nigerian masa from mixtures of rice, millet, cowpea and groundnut. Food Nutrition Bulletin 19 (4):1-50.

NIH Publication \#85-23 (1985). Respect for life. National Institute of Environmental. Health Sci. http://www.niehs.gov/oc/factsheets/wri/studybgn.h.t.m.

Okunrobo, O., Uwaya, O. J., Imafidon, E.K., Osarumwense, O.P. and Omorodion, E.J. (2012). Qualitative determination, metal content analysis and antiulcer evaluation of methanol seed extract of Citrullus lanatus Thunb. (Cucurbitaceae)in rats. Asian Pac. J. Trop. Dis. S804S808.

Oyeleke, A.O. (1988). Effect of consumption of kanwa in food and water on certain physiological states in rats. Nutr. 4:137-140

Oyeleke, O.A. and Morton, I. A. (1981). Improvement of lysine availability from cowpeas cooked with kanwa. Nig. J. Nutr. Sci. $1: 120-123$.

SKOOG, D. A., HOLLER F. J. and CROUCH, S. R. (2007). Atomic absorption and atomic fluorescence spectrometry In: Principles of Instrumental Analysis. Pp301 (BROOKS/COLE ) C. A. United States. Sodipo,O.A., Akpan, A.E., Ajayi, O.O. and Akanji, M.A. (1993). Effect of normal consumption of trona (kanwa) a local mineral salt lick and human erythrocyte- 1 In: Abstracts from the $5^{\text {th }}$ International Chemistry Conference in Africa, Gaborone, Botswana, pp36. 